\title{
Analysis Inner-Outer Model Analysis of Emotional Intelligence and Performance of Staff from the Ministry of Religion in Kota Batam, Indonesia
}

\author{
Mukhlishotul Jannah ${ }^{1}$ and Hazriyanto ${ }^{2}$ \\ Faculty of Islamic Economy and Business, UIN Sultan Maulana Hasanuddin Banten, \\ Indonesia $^{1}$ \\ Faculty of Economics and Management, STIE Galileo, Batam, Indonesia² \\ ndelisa13@gmail.com¹, hazriyanto@gmail.co²
}

\begin{abstract}
The question that is frequently posed in general is how to create human resources that is capable of producing optimal performance, which eventually leads to the realization of the organization's objectives. Numerous factors influence a person's performance, which could eventually lead to organizational performance, work stress problems, emotional intelligence and performance; hence, these factors deserve attention. The variables in this study were emotional intelligence and performance of staff from the Ministry of Religion in Kota Batam. The tool for collecting data was the questionnaire and it was analysed using the SEM statistical tool and SmartPLS software. The evaluation involved 28 items on emotional intelligence and 6 items on performance. The population and sample in this study comprised 30 staff as respondents. The findings showed that emotional intelligence and performance have a positive and significant relationship. It was suggested that future studies look into the demographic aspects as well as other variables that were not included in this study, such as commitment, spiritual motivation and work satisfaction.
\end{abstract}

Keywords: Emotional Intelligence, Performance, Officer, Ministry of Religion.

\section{Introduction}

Contemporary human resources development should be seen as a part of the organization and society's needs and not solely on national interest. Staff are capable of enhancing the quality, provide services as well as overcome problems, either individually or in a group. It should be realised that the involvement of staff from the Ministry of Religion in Kota Batam in providing public service should be included in the planning, implementation, utilization and evaluation processes. Staff should be capable of achieving a desired level of performance, which is one of the essential components in the service system in the Ministry of Religion, Kota Batam.

A study on the effects of training and development of staff on employee's performance based on the level of job satisfaction was implemented in Pakistan. The findings showed a positive effect of development and training as well as job satisfaction on work performance. 
Training and development leads to a higher level of job satisfaction among staff and they can fulfil their duties with full responsibility culminating in very good performances [1].

Another study was related to work stress and performance among public sector employees in Istanbul and investigated the moderating role of emotional intelligence. This study involved public sector employees and investigated the relationship between work stress and work performance while considering emotional intelligence as the moderating variable. The findings showed a negative relationship between work stress and work performance, while emotional intelligence had a positive relationship with work performance [2].

Other studies were related to important precursors and the effects of employee's creativity in the service, employee's emotional strategy and official work performance. Employee's creativity in the service organization confirms that emotional fatigue and affective commitment are motivational factors in the employee's emotional strategy, which influences service employees' creativity and suggests the value of the employee's creativity [3].

One study was related to the structural model relationship between the emotional intelligence dimension, conflict management and work performance. The findings from the structural fitness model showed that there was no positive and significant effect between the variables in the study. Besides that, the role of the moderator in conflict management in this study using the SERVQUAL model in the relationship between emotional intelligence and work performance was verified [4].

Numerous factors contribute to the staff's performance, such as work stress, emotional intelligence, job satisfaction etc. Staff's emotional intelligence is a contributing factor to organizational production. Hence, these findings had encouraged the researcher to carry out a study entitled "Emotional Intelligence and Job Performance of Staff from the Ministry of Religion in Kota Batam". The limitations of the study were mainly regarding emotional intelligence and staff's performance.

A summary of the problem in this study is as follows;

1. Does emotional intelligence have an influence on the performance of staff in the Ministry of Religion in Kota Batam?

The aim of this study was to determine the influence of emotional intelligence on the performance of staff in the Ministry of Religion in Kota Batam.

Measuring emotional intelligence and performance of staff from the Ministry of Religion, Kota Batam based on the staff's perception was implemented by evaluating the items regarding emotional intelligence and performance appropriate with the literature review relevant to its adaptation/adoption [2].

A study by Uğur Yozgat et al., (2013) showed that emotional intelligence had a positive effect on work performance. Meanwhile, [3] also showed a relationship between employees' emotions and their related work performance. The results showed that the relationship between the employee's emotional strategy and work performance was moderated by job satisfaction. Previous studies had related conflict management styles, emotional intelligence and work performance in a public organization. The results showed that EI in an public organization had an effect on work performance [8].

\section{Method}

One important element in a study is to plan the design of the study. This particular study was a quantitative descriptive study and it was implemented in the offices of the Ministry of Religion in Kota Batam located in Jl. Masjid Baiturrahman Sekupang Batam. This study had used the census technique whereby the whole population was presumed to be the sample, which comprised 30 respondents who were staff from the Ministry of Religion, Kota Batam. 
All the staff had participated voluntarily by filling in the questionnaire and they were given a briefing about the objectives of the study by the researcher.

The variables in this study were emotional intelligence and performance. The items in the emotional intelligence and performance instrument were adopted/adapted from Uğur Yozgat et al. (2013).

Emotional intelligence had 28 items, such as;

1. When I am faced with obstacles, I remember times I faced similar obstacles and overcame them.

2. I expect that I will do well on must things I try.

3. Other people find it easy to confide in me

4. Some of the major events of my life have led me to re-evaluate what is important and not important

5. When my mood changes, I see new possibilities.

6. Emotions are one of the things that make my life worth living

7. I am aware of my emotions as I experience them.

8. I expect good thing to happen.

9. I like to share my emotions with others.

10. When I experience a positive emotion, I know how to make it last

11. I arrange events others enjoy

12. I seek out activities that make me happy

13. I am aware of non-verbal messages I send to others.

14. I present myself in a way that makes a good impression on others

15. When I am in a positive mood, solving problems is easy for me

16. By looking at their facial expressions, I recognize the emotions people are experiencing.

17. I know why my emotions change.

18. When I am in a positive mood, I am able to come up with new ideas.

19. I easily recognize my emotions as I experience them.

20. I motivate myself by imaging a good outcome to tasks I take on.

21. I compliment others when they have done something well.

22. I am aware of non-verbal messages other people send.

23. When another person tells me about an importance event in his or her life, I almost feel as though I have experienced this event myself.

24. I know what other people are feeling just by looking at them.

25. I help other people feel better when they are down.

26. I use good moods to help myself keep trying in the faceoff obstacles

27. I can tell how people are feeling by listening to the tone of their voice

28. It is difficult for me to understand why people feel the way they do

Meanwhile, Performance comprised 6 items, such as;

1. How would you rate yourself in terms of the quantity of work you achieve?

2. How do you rate yourself in terms of your ability to reach your goals?

3. How do you rate yourself in terms of your performance potential among co-workers in your company?

4. How do you rate yourself in terms of quality of your performance in regards to customer relations?

5. How do you rate yourself in terms of quality of your performance in regards to management of time, planning ability, and management of expenses? 
6. How do you rate yourself in terms of quality of your performance in regards to knowledge of your products, company, competitors' products, and customer needs?

This study employed the quantitative approach and data were obtained using the questionnaire that was developed by the researcher with respondents comprising staff from the Ministry of Religion, Kota Batam. The questionnaire comprised 34 items pertaining to emotional intelligence and performance.

The data collection technique in this study used the questionnaire and primary data comprised data obtained by the researcher via the questionnaire (survey method), which was completed by the respondents (staff from the Ministry of Religion, Kota Batam).

The respondents answered each item based on five choices and the answers showed whether they were inclined to move to the extreme left or right column, which indicates a positive or negative emotional intelligence and performance for each item.

The model of the study is as follows:

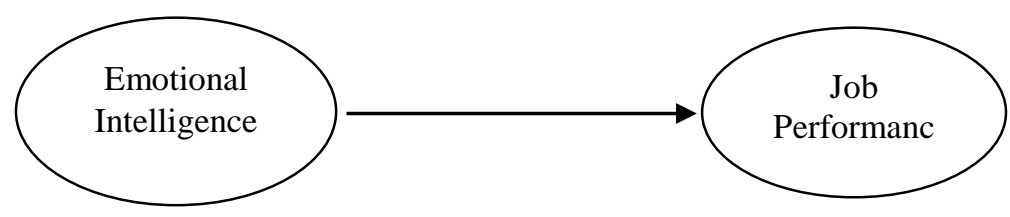

Fig. 1. Emotional Intelligence and Job Performance

The data analysis had used the descriptive correlation analysis by considering the emotional intelligence factor on performance. This measurement was chosen because the researcher was aware of differences in the characteristics of the evaluator when evaluating the staff.

The data analysis in this study intended to determine the quantity and percentage of the respondent's demographic characteristics. The analysis comprised descriptive statistics that used the variance-based statistical tool called SEM SmartPLS.

Next, the emotional intelligence variable's effect on performance among staff from the Ministry of Religion, Kota Batam was analyzed using the SEM analysis that employed the Smart PLS 2.0 Partial Least Square (PLS) software. Partial Least Square (PLS) is one of the techniques in Structural Equation Modelling (SEM) that is capable of directly analyzing latent variables, indicator variables and measurement errors.

PLS is a powerful method of analysis because it can be assimilated in all data scales, does not involve much assumption and the measurement sample is not too large. Besides being used for confirmation of theories, PLS can also be used to develop relations that do not yet have a theoretical platform or to test propositions.

Analysis of relations between variables and indicators involves the Outer Model and Inner Model tests. The Outer model or measurement model, in principle, is used to test the indicator of latent variables or in other words, to measure how far the indicator can explain the latent variable. The reflective indicator was tested for convergent validity, discriminant validity or average variance extracted (AVE) and composite reliability. The Inner Model or structural model, in principle, tests the influence between two latent variables; whether it is exogenous or endogenous. It could also refer to testing a hypothesis between two latent variables. The test is done by looking into the percent variance as explained, which is $\mathrm{R}^{2}$, for the dependent latent variable that is modelled to obtain the influence from the independent latent variable by using 
the Stone-geisser Q square test measurement, as well as determining the value of the structural path coefficient. The estimation's stability was tested using the t-statistic test that was obtained through the bootstrapping procedure. The table shows the criteria for the evaluation.

Table 1. Test Model [9].

\begin{tabular}{|c|c|c|}
\hline Test Model & Output & Criteria \\
\hline \multirow{4}{*}{$\begin{array}{l}\text { Outer } \quad \text { Model } \\
\text { (Indicator Test) }\end{array}$} & a. Convergent Validity & $\begin{array}{l}\text { a. A Loading factor value of } 0.50 \text { to } 0.60 \text { is } \\
\text { sufficient }\end{array}$ \\
\hline & b. Discriminant Validity & $\begin{array}{l}\text { b. Correlation value of Cross Loading with } \\
\text { its latent variable should be bigger compared } \\
\text { to the correlation value of other latent } \\
\text { variables }\end{array}$ \\
\hline & $\begin{array}{l}\text { c. Average Variance } \\
\text { Extracted }(A V E)\end{array}$ & c. AVE value should be more than 0.50 \\
\hline & d. Composite Reliability & $\begin{array}{l}\text { d. A good composite reliability value when it } \\
\text { is } \geq 0.70\end{array}$ \\
\hline \multirow{2}{*}{$\begin{array}{l}\text { Inner } \quad \text { Model } \\
\text { (Hypothesis Test) }\end{array}$} & $\begin{array}{l}\text { a. } \mathrm{R}^{2} \text { latent variable } \\
\text { endogen }\end{array}$ & $\begin{array}{l}\text { a. Result of the } \mathrm{R}^{2} \text { such as } 0.67 ; 0.30 ; 0.19 \\
\text { indicates a "Good", "Moderate" and "Weak" } \\
\text { model, respectively }\end{array}$ \\
\hline & $\begin{array}{l}\text { b. Parameter Coefficient } \\
\text { and t- Statistic }\end{array}$ & $\begin{array}{l}\text { b. Estimated value for the path relationship in } \\
\text { the structural model should be significant, } \\
\text { which could be obtained with the } \\
\text { bootstrapping procedure }\end{array}$ \\
\hline
\end{tabular}

Thus, if an item is consistently placed in a particular category, then it could be assumed to indicate convergent validity with a related construct, while the discriminant validity with other constructs. The reliability scale is generally evaluated according to the Cronbach's Alpha (Cronbach, 1984). Nunnaly suggested that at the early part of the research the a reliability value within the range of 0.05 to 0.60 is presumed adequate [10]. Generally, the accepted reliability score in most studies is between 0.70 to 0.80 .

Table 2. Limits to the Cronbach's Alpha Reliability Score [10]

\begin{tabular}{|c|c|}
\hline Score & Reliability \\
\hline$<0.50$ & Low \\
\hline $0.50-0.60$ & Moderate \\
\hline $0.70-0.80$ & Tinggi \\
\hline
\end{tabular}

\section{Result and Discussion}

Respondents' data from this study are in the Table below:

Table 3. Respondent's Data

\begin{tabular}{|c|c|}
\hline Gender & Total \\
\hline Male & 12 \\
\hline Female & 18 \\
\hline Total & 30 \\
\hline
\end{tabular}


Table 3 shows that the total number of respondents in this study comprised 12 males and 18 females totalling 30 respondents in all. Next, the results of the validation tests on the variable items are shown in the following Table.

\subsection{Indicator Test / Outer Model with SEM SmartPLS}

The Outer model specifies the relationship between the latent variable and its indicators. As for the first test in this study's model for the indicator test (measurement model), the indicators were presumed to be valid if the minimum loading factor value was 0.50 . More details about the values are found in the Table below.

Table 4. Validity Test

\begin{tabular}{|c|c|c|c|}
\hline Validity & Influence & Original Sample & Status \\
\hline \multirow{34}{*}{$\begin{array}{c}\text { Outer Loading } \\
\text { (Convergent } \\
\text { Validity) }\end{array}$} & EI1 & 0,332829 & Invalid \\
\hline & EI10 & 0,697684 & Valid \\
\hline & EI11 & 0,28991 & Invalid \\
\hline & EI12 & 0,719178 & Valid \\
\hline & EI13 & 0,392769 & Invalid \\
\hline & EI14 & 0,530466 & Valid \\
\hline & EI15 & 0,618952 & Valid \\
\hline & EI16 & 0,622716 & Valid \\
\hline & EI17 & 0,501235 & Valid \\
\hline & EI18 & 0,626931 & Valid \\
\hline & EI19 & 0,657582 & Valid \\
\hline & EI2 & 0,597077 & Valid \\
\hline & EI20 & 0,822675 & Valid \\
\hline & EI21 & 0,790886 & Valid \\
\hline & EI22 & 0,507847 & Invalid \\
\hline & EI23 & 0,65719 & Valid \\
\hline & EI24 & 0,248363 & Invalid \\
\hline & EI25 & 0,322898 & Invalid \\
\hline & EI26 & 0,61136 & Valid \\
\hline & EI27 & 0,445611 & Invalid \\
\hline & EI28 & 0,154837 & Invalid \\
\hline & EI3 & 0,49683 & Invalid \\
\hline & EI4 & 0,664608 & Valid \\
\hline & EI5 & 0,553798 & Valid \\
\hline & EI6 & 0,246167 & Invalid \\
\hline & EI7 & 0,329711 & Invalid \\
\hline & EI8 & 0,698113 & Valid \\
\hline & EI9 & 0,768304 & Valid \\
\hline & JP1 & 0,832845 & Valid \\
\hline & JP2 & 0,805545 & Valid \\
\hline & JP3 & 0,826849 & Valid \\
\hline & JP4 & 0,820452 & Valid \\
\hline & JP5 & 0,822688 & Valid \\
\hline & JP6 & 0,846862 & Valid \\
\hline
\end{tabular}


A second test should be carried out because the first test had some invalid data. For the second test from the study's model, a more detailed explanation of the above values is shown in the Table below.

Table 5. Validity Test

\begin{tabular}{|c|c|c|c|}
\hline Validity & Influence & Original Sample & Status \\
\hline \multirow{24}{*}{$\begin{array}{l}\text { Outer Loading } \\
\text { (Convergent } \\
\text { Validity) }\end{array}$} & EI10 & 0,715236 & Valid \\
\hline & EI12 & 0,726784 & Valid \\
\hline & EI14 & 0,541462 & Valid \\
\hline & EI15 & 0,606621 & Valid \\
\hline & EI16 & 0,638615 & Valid \\
\hline & EI17 & 0,49426 & Invalid \\
\hline & EI18 & 0,609173 & Valid \\
\hline & EI19 & 0,666986 & Valid \\
\hline & EI2 & 0,573469 & Valid \\
\hline & EI20 & 0,817702 & Valid \\
\hline & EI21 & 0,803932 & Valid \\
\hline & EI22 & 0,465308 & Invalid \\
\hline & EI23 & 0,666338 & Valid \\
\hline & EI26 & 0,639816 & Valid \\
\hline & EI4 & 0,664774 & Valid \\
\hline & EI5 & 0,572085 & Valid \\
\hline & EI8 & 0,695965 & Valid \\
\hline & EI9 & 0,784302 & Valid \\
\hline & JP1 & 0,835719 & Valid \\
\hline & JP2 & 0,810134 & Valid \\
\hline & JP3 & 0,822607 & Valid \\
\hline & JP4 & 0,815884 & Valid \\
\hline & JP5 & 0,820313 & Valid \\
\hline & JP6 & 0,846174 & Valid \\
\hline
\end{tabular}

Another test was carried out because the second test contained some invalid data. For the third test from the study's model, a more detailed explanation of the above values is shown in the Table below.

Table 6. Validity and Reliability Tests

\begin{tabular}{|c|c|c|c|}
\hline $\begin{array}{l}\text { Validity and } \\
\text { Reliability }\end{array}$ & Influence & Original Sample & Status \\
\hline \multirow{8}{*}{$\begin{array}{l}\quad \text { Outer } \\
\quad \text { Loading } \\
\text { (Convergent } \\
\text { Validity) }\end{array}$} & EI10 & 0,724976 & Valid \\
\hline & EI12 & 0,731936 & Valid \\
\hline & EI14 & 0,557891 & Valid \\
\hline & EI15 & 0,601936 & Valid \\
\hline & EI16 & 0,635092 & Valid \\
\hline & EI18 & 0,604953 & Valid \\
\hline & EI19 & 0,662927 & Valid \\
\hline & EI2 & 0,548346 & Valid \\
\hline
\end{tabular}




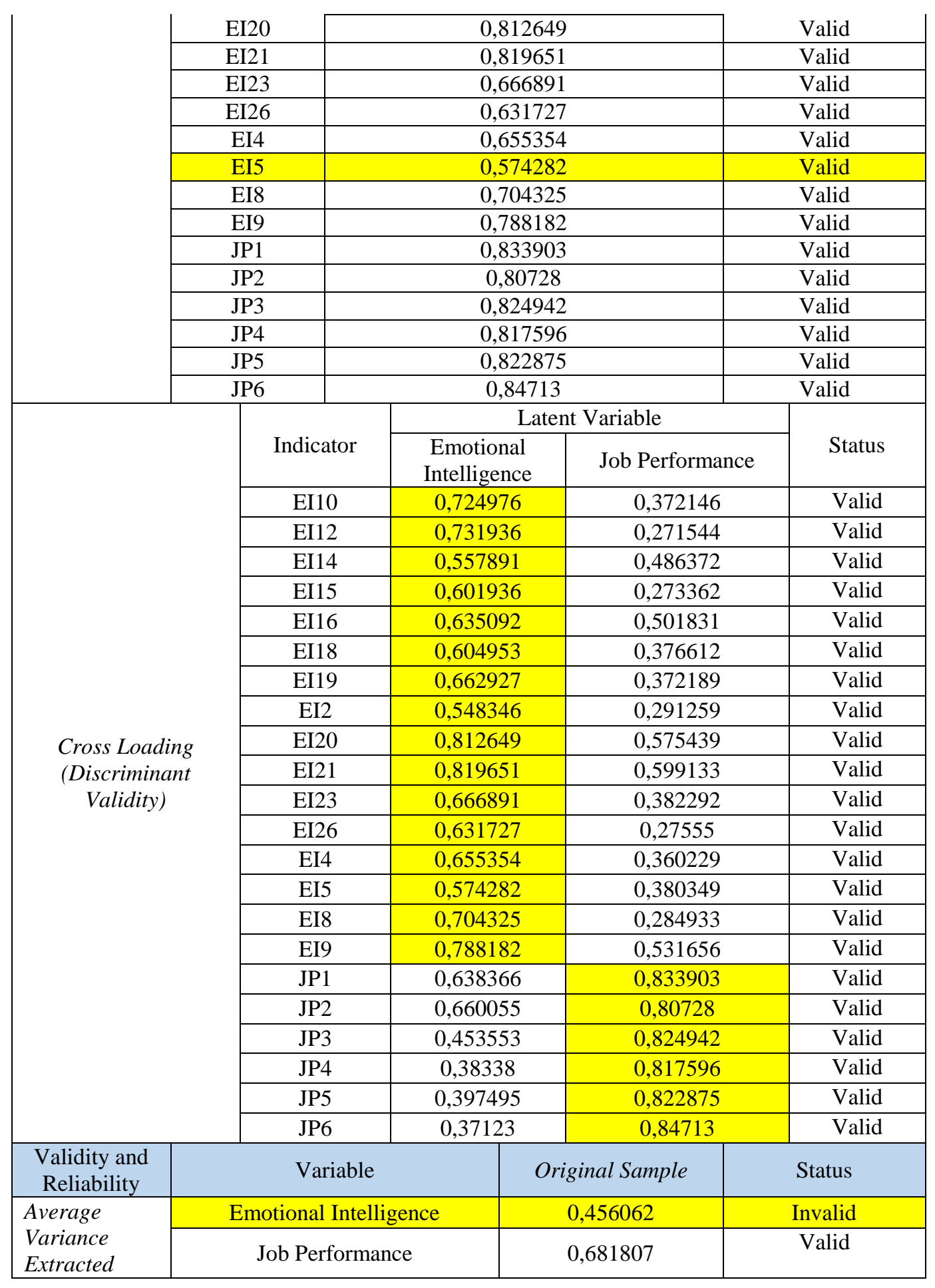




\begin{tabular}{|c|c|c|c|}
\hline$(A V E)$ & & & \\
\hline \multirow{2}{*}{$\begin{array}{l}\text { Composite } \\
\text { Reliability }\end{array}$} & Emotional Intelligence & 0,929613 & Valid \\
\hline & Job Performance & 0,927816 & Valid \\
\hline
\end{tabular}

Data from the third test involving the loading factor value from $A V E$, which was Emotional Intelligence, was invalid because it was below 0.50. For the fourth test from the study's model, the results of the test for the loading factor value from AVE, which was Emotional Intelligence, was invalid because it was below 0.50. A more detailed explanation of the values is found in the table below.

Table 7. Average Variance Extracted (AVE) and Composite Reliability Tests

\begin{tabular}{|c|c|c|c|}
\hline Validity and Reliability & Variable & Original Sample & Status \\
\hline $\begin{array}{c}\text { Average Variance Extracted } \\
(A V E)\end{array}$ & Emotional Intelligence & 0,494301 & Invalid \\
\cline { 2 - 4 } Composite Reliability & Job Performance & 0,679614 & Valid \\
\cline { 2 - 4 } & Emotional Intelligence & 0,926169 & Valid \\
\cline { 2 - 4 } & Job Performance & 0,927132 & Valid \\
\hline
\end{tabular}

Data from the fourth test involving the loading factor value from $A V E$, which was Emotional Intelligence, was invalid because it was below 0.50. For the fifth test from the study's model, the data from the fifth test involving the loading factor value was valid because it was above 0.50. Detailed explanations for the values in the fifth test are found in the Table and Diagram below.

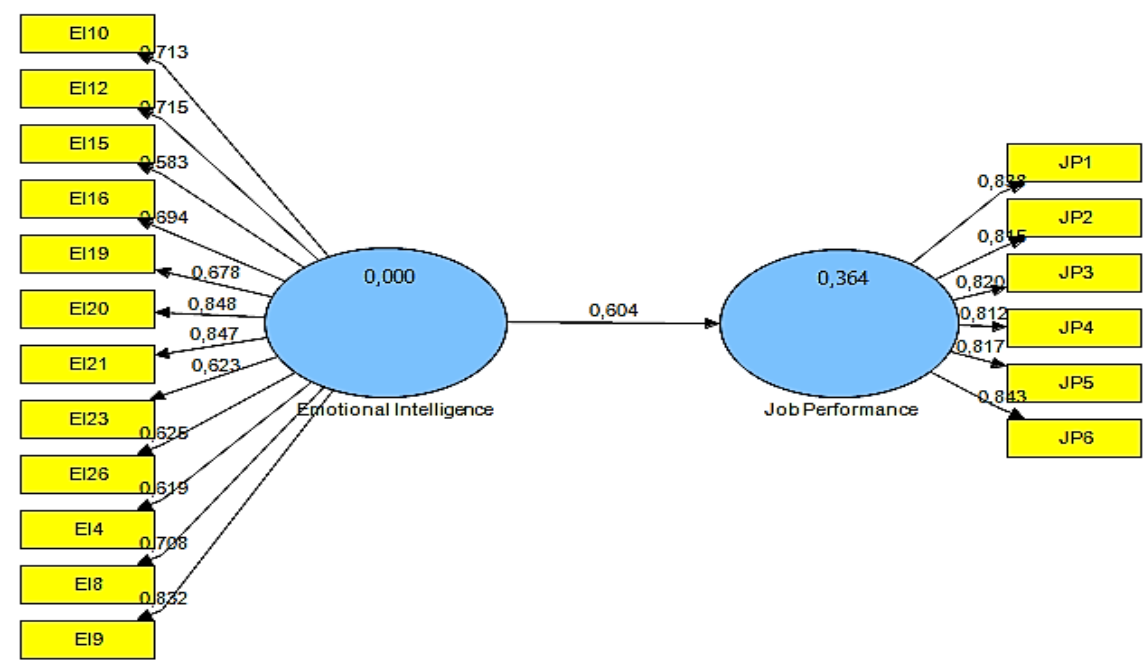

Fig. 2. Results of the Algorithm PLS test after discarding the Invalid Indicators

Table 8. Validity and Reliability Tests

\begin{tabular}{|c|c|c|c|}
\hline Validity and Reliability & Influence & Original Sample & Status \\
\hline $\begin{array}{c}\text { Outer Loading } \\
\text { (Convergent Validity) }\end{array}$ & EI10 & 0,712921 & Valid \\
\cline { 2 - 4 } & EI12 & 0,714571 & Valid \\
\hline
\end{tabular}




\begin{tabular}{|c|c|c|c|c|}
\hline & EI15 & \multicolumn{2}{|c|}{0,582692} & Valid \\
\hline & EI16 & \multicolumn{2}{|c|}{0,693969} & Valid \\
\hline & EI19 & \multicolumn{2}{|c|}{0,677688} & Valid \\
\hline & EI20 & \multicolumn{2}{|c|}{0,847961} & Valid \\
\hline & EI21 & \multicolumn{2}{|c|}{0,847379} & Valid \\
\hline & EI23 & \multicolumn{2}{|c|}{0,622862} & Valid \\
\hline & EI26 & \multicolumn{2}{|c|}{0,625168} & Valid \\
\hline & EI4 & \multicolumn{2}{|c|}{0,61895} & Valid \\
\hline & EI8 & \multicolumn{2}{|c|}{0,708343} & Valid \\
\hline & EI9 & \multicolumn{2}{|c|}{0,832246} & Valid \\
\hline & JP1 & \multicolumn{2}{|c|}{0,838184} & Valid \\
\hline & JP2 & \multicolumn{2}{|c|}{0,815012} & Valid \\
\hline & JP3 & \multicolumn{2}{|c|}{0,819649} & Valid \\
\hline & JP4 & \multicolumn{2}{|c|}{0,812434} & Valid \\
\hline & JP5 & \multicolumn{2}{|c|}{0,816922} & Valid \\
\hline & JP6 & \multicolumn{2}{|c|}{0,843324} & Valid \\
\hline \multirow{20}{*}{$\begin{array}{c}\text { Cross Loading } \\
\text { (Discriminant Validity) }\end{array}$} & \multirow[b]{2}{*}{ Indicator } & \multicolumn{2}{|c|}{ Latent Variable } & \multirow[b]{2}{*}{ Status } \\
\hline & & $\begin{array}{l}\text { Emotional } \\
\text { Intelligence }\end{array}$ & Job Performance & \\
\hline & EI10 & 0,712921 & 0,37644 & Valid \\
\hline & EI12 & 0,714571 & 0,276026 & Valid \\
\hline & EI15 & 0,582692 & 0,279129 & Valid \\
\hline & EI16 & 0,693969 & 0,507205 & Valid \\
\hline & EI19 & 0,677688 & 0,378485 & Valid \\
\hline & EI20 & 0,847961 & 0,581237 & Valid \\
\hline & EI21 & 0,847379 & 0,604074 & Valid \\
\hline & EI23 & 0,622862 & 0,388511 & Valid \\
\hline & EI26 & 0,625168 & 0,280917 & Valid \\
\hline & EI4 & 0,61895 & 0,365983 & Valid \\
\hline & EI8 & 0,708343 & 0,288148 & Valid \\
\hline & EI9 & 0,832246 & 0,537419 & Valid \\
\hline & JP1 & 0,621606 & 0,838184 & Valid \\
\hline & JP2 & 0,661699 & 0,815012 & Valid \\
\hline & JP3 & 0,430195 & 0,819649 & Valid \\
\hline & JP4 & 0,346727 & 0,812434 & Valid \\
\hline & JP5 & 0,361151 & 0,816922 & Valid \\
\hline & JP6 & 0,329535 & 0,843324 & Valid \\
\hline Validity and Reliability & & & Original Sample & Status \\
\hline Average Variance & Emoti & lligence & 0,507718 & Valid \\
\hline Extracted (AVE) & & lance & 0,679538 & Valid \\
\hline 4. & Emoti & lligence & 0,924165 & Valid \\
\hline Composite Reliability & & ance & 0,927115 & Valid \\
\hline
\end{tabular}


Based on the diagram and table above, it could be stated that all the indicators were valid because the factor loading values were greater than 0.50 and the composite reliability for all the variable were reliable because the loading value was more than 0.70 .

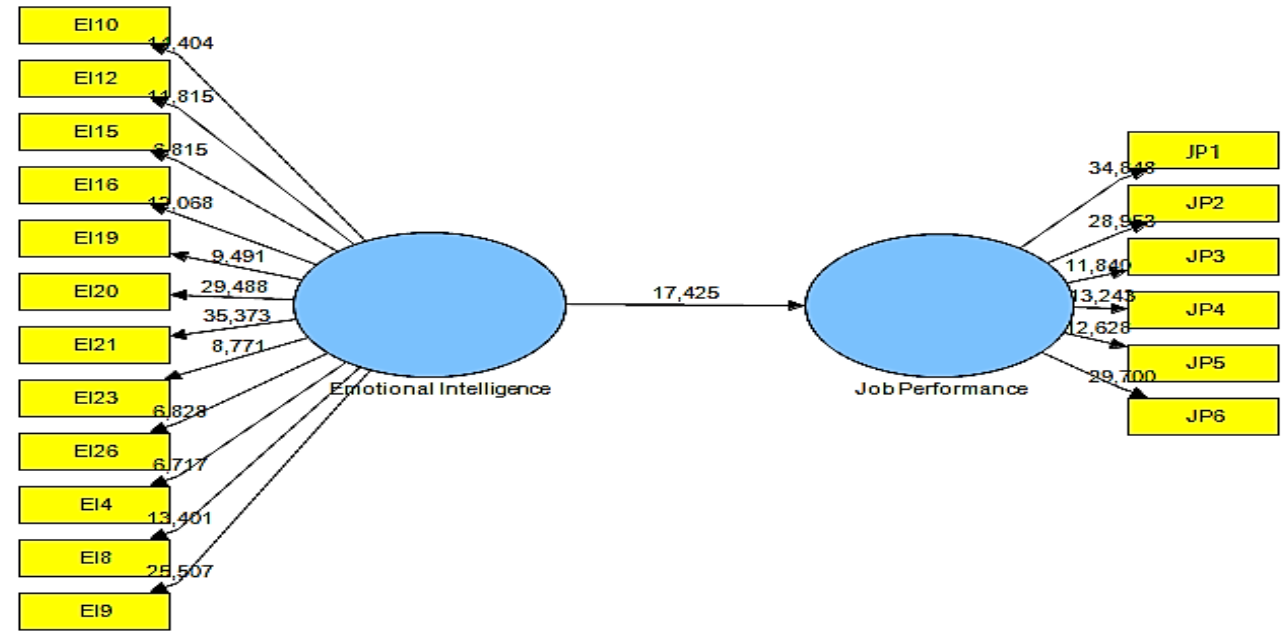

Fig. 3. Bootstrapping

related the t-statistic test. The values explain the hypothesis in this study. The test results are put in the form of tables to facilitate the analysis of the findings in this study. Following is a more detailed description of the values obtained from the test on the data above.

Table 9. AVE, Composite Reliability, R-Square, Cronbach's Alpha

\begin{tabular}{|c|c|c|c|c|c|c|c|c|}
\hline Indicator & $A V E$ & Status & $\begin{array}{l}\text { Composite } \\
\text { Reliability } \\
\end{array}$ & Status & $R$ Square & Status & $\begin{array}{c}\text { Cronbach's } \\
\text { Alpha }\end{array}$ & Status \\
\hline $\begin{array}{l}\text { Emotional } \\
\text { Intelligence }\end{array}$ & 0,507718 & Valid & 0,924165 & \multirow{2}{*}{ Reliable } & & & 0,910635 & \multirow{2}{*}{ Reliable } \\
\hline $\begin{array}{l}\text { Job } \\
\text { Performance }\end{array}$ & 0,679538 & Valid & 0,927115 & & 0,364259 & Moderate & 0,909188 & \\
\hline
\end{tabular}

The interpretation of Table 9 above is as follows:

1. The AVE value for the variables was 0.50 , meaning it was valid.

2. The composite reliability value for all the variables was valid because the value was more than 0.70 .

3. R-square value for the job performance variable was moderate.

4. Cronbach's alpha value for all the variables was Reliable because the value was more than 0.70 .

\subsection{Structural Test (Influence test/Hypothesis test)}

The Inner model tested the influence of one latent variable on another latent variable, either an exogenous or endogenous variable. 
Table 10. Structural Test (Influence test/Hypothesis test) after the Indicator Test

\begin{tabular}{|c|c|}
\hline Test & Results of the Test \\
\hline Determinant Coefficient $\mathbf{R}^{\mathbf{2}}$ & 0.364259 \\
\hline Job Performance & \\
\hline T- Statistic & 17.42544 \\
\hline Emotional Intelligence $\rightarrow$ Job Performance & 0.603538 \\
\hline Parameter Coefficient & \\
\hline Emotional Intelligence $\rightarrow$ Job Performance &
\end{tabular}

Elaborations of the findings of the test above are as follows:

Structural Test (Influence test/Hypothesis test)

1. Determinant Coefficient $R^{2}$

Shows that emotional intelligence contributed to job performance by $36.42 \%$, while the remainder $63.58 \%$ was influenced by another factor that was not found in the model. This means that job performance was influenced by emotional intelligence by $36.42 \%$, while 63.58 $\%$ was influenced by another variable not investigated in this study.

\section{T-statistic}

The t-statistic test results for the exogenous and endogenous variables are stated and the influence of emotional intelligence on job performance was significant because its t-statistic value was above the $\mathrm{t}$-table ( $\mathrm{t}-$ table with a significance of $5 \%$ and $\mathrm{DF}=30$, was equivalent to 2.0422).

\section{Parameter Coefficient}

The parameter coefficient of emotional intelligence to job performance was 0.6035 , meaning that the positive influence by emotional intelligence on job performance was 0.6035 . Hence, the higher the emotional intelligence, higher the job performance.

The findings of the test showed that the relationship between emotional intelligence and job performance was 0.6035 , which was in the moderate category [11]. The relations of both the variables was significant. The findings of the study was consistent with that of other [2], [12]. The findings were also consistent with previous studies whereby there was a relationship between emotional intelligence and job performance [13].

\section{Conclusion}

According to the findings and discussions in this study, the following conclusions were made;

1. Influence of emotional intelligence on job performance

There was an influence by emotional intelligence on job performance by $36.42 \%$.

2. Relationship between emotional intelligence and job performance

There was a moderate and significant relationship between intelligence and job performance

This relationship should be maintained and receive greater attention since the there is a strong relationship among the related variables.

\section{Acknowledgements}

I would like to extend my deepest gratitude to Dr. Erizal, Head of the Ministry of Religion, Kota Batam and his colleagues, Mr. Hazriyanto, Lecturer at STIE Galileo and fellow lecturers in UIN Sultan Maulana Hasanuddin Banten. 


\section{References}

[1] S. Osama, B. Haseeb, R. M. Waseem, M. Ayaz, and M. Ijaz, "Impact of Training and Development of Employees on Employee Performance through Job Satisfaction: A Study of Telecom Sector of Pakistan," vol. 7, no. 1, pp. 29-46, 2016.

[2] U. Yozgat, S. Yurtkoru, and E. Bilginoğlu, "Job stress and job performance among employees in public sector in Istanbul: examining the moderating role of emotional intelligence," Procedia - Soc. Behav. Sci., vol. 75, pp. 518-524.

[3] I. Shin, W.-M. Hur, and H. Oh, "Essential precursors and effects of employee creativity in a service context Emotional labor strategies and official job performance," Career Dev. Int., vol. 20, no. 7, pp. 733-752, 2015.

[4] H. Heidari and H. A. Heidari, "A structural model for relationship between dimensions of emotional intelligence , conflict management and job performance of the staff ( Case study: Ilam Gas Refinement Corporation ),"World Sci. News, vol. 44, pp. 192-205, 2016.

[5] S. P. Robbins and T. A. Judge, Perilaku Organisasi, 2nd ed. Jakarta, 2008.

[6] Wibowo, Manajemen Kinerja, 3rd ed. Jakarta: Rajawal Pers.

[7] D. Goleman, Emotional Intelligence. Jakarta: PT Gramedia Pustaka Utama.

[8] H.-A. Shih and E. Susanto, "Conflict management styles, emotional intelligence , and job performance in public organizations," Int. J. Confl. Manag., vol. 21, no. 2, pp. 147$168,2010$.

[9] G. Wiyono, 3 in One Merancang Penelitian Bisnis dengan Alat Analisis SPSS 17.0 \& SmartPLS 2.0, Pertama. Yogyakarta: Unit Penerbit Percetakan STIM YKPN, 2011.

[10] Jogiyanto, Konsep dan Aplikasi Sructural Equation Modeling (SEM) Berbasis Varian dalam Penelitian Bisnis (Cetakan Pe). Yogyakarta: Unit Penerbit Percetakan STIM YKPN.

[11] J. Cohen, Statistical power analysis for the behavioural sciences, 2nd ed. Hillsdale, NJ: Lawrence Erlbaum Associates.

[12] H.-A. Shih and E. Susanto, "Conflict management styles , emotional intelligence , and job performance in public organizations,” Int. J. Confl. Manag., vol. 21, no. 2, pp. $147-$ 168.

[13] W.-M. Hur, S.-J. Han, J.-J. Yoo, and T. W. Moon, "The moderating role of perceived organizational support on the relationship between emotional labor and job-related outcomes," Manag. Decis., vol. 53, no. 3, pp. 605-624. 